\title{
PERBANDINGAN HASIL BELAJAR MENGGUNAKAN STRATEGI PEMBELAJARAN LEARNING START WITH A QUESTION DENGAN A QUESTION STUDENT HAVE
}

\author{
Yati Oktafia, Muhammad Wayong, Andi Jusriana.
}

\author{
Pendidikan Fisika, Fakultas Tarbiyah dan Keguruan, UIN Alauddin Makassar, yatioktafia10@gmail.com
}

\begin{abstract}
Abstrak
Tujuan penelitian dalam penelitian ini adalah 1) Untuk mengetahui hasil belajar fisika siswa yang diajar dengan menggunakan strategi pemelajaran LSQ pada pokok bahasan suhu dan kalor, 2) Untuk mengetahui hasil belajar fisika siswa yang diajar dengan menggunakan strategi pembelajaran QSH pada pokok bahasan suhu dan kalor dan 3) Untuk mengetahui ada tidaknya perbedaan hasil belajar fisika siswa yang diajar dengan menggunakan strategi pembelajaran LSQ dengan yang diajar dengan menggunakan strategi pembelajaran QSH pada pokok bahasan suhu dan kalor. Jenis penelitian yang digunakan adalah penelitian eksperimen. Populasi seluruh siswa kelas X SMAN 1 Sano Nggoang yang terdiri dari 4 kelas. Teknik pengambilan sampel adalah purposive. Adapun sampel penelitian adalah siswa kelas $X A$ dan siswa kelas XB masing-masing kelas berjumlah 22 orang siswa. Teknik pengambilan data dengan menggunakan instrument test berbentuk soal pilihan ganda sejumlah 20 nomor. Teknik analisis data menggunakan analisis statistik deskriptif dan inferensial. Hasil penelitian yang diperoleh dari kedua kelompok tersebut melalui analisis statistik deskriptif, rata-rata hasil belajar fisika dengan mengguanakan strategi pembelajaran LSQ sebesar = 69,36 sedangkan rata-rata QSH sebesar = 45,77. Hasil belajar fisika siswa yang diajar dengan menggunakan strategi pembelajaran LSQ lebih tinggi dibandingkan QSH. Perbedaan tersebut dapat dilihat pada skor rata-rata kelas eksperimen 1 dan kelas eksperimen 2. Hasil analisis inferensial data menunjukkan bahwa nilai signifikan yang diperoleh thitung 10,08 > ttabel 2,021 dan signifikan $\alpha=0$,05. Sehingga dapat disimpulkan bahwa ada peningkatan hasil belajar dari penggunaan strategi pembelajaran LSQ terhadap hasil belajar fisika peserta didik.
\end{abstract}

Kata kunci: Hasil belajar, LSQ dan QSH.

\section{Pendahuluan}

Pendidikan merupakan kebutuhan sekaligus hak dasar bagi setiap warga Negara, tanpa membedakan golongan, gender, usia, status sosial maupun tempat tinggal. Hal ini berarti setiap warga negara memiliki hak yang sama untuk memperoleh layanan pendidikan. Oleh karena itu, pemerintah senantiasa dituntut untuk terus melakukan upaya motivasi agar dapat memberikan layanan pendidikan yang dapat menjangkau seluruh lapisan masyarakat.

Proses belajar mengajar merupakan salah satu bentuk kegiatan yang dilakukan oleh guru dengan peserta didik dalam lingkungan belajar. Guru mempunyai peran penting saat berlangsungnya kegiatan proses belajar mengajar. Oleh karena itu untuk mencapai tujuan dimana tujuan yang diharapkan guru adalah hasil belajar dari peserta didik tersebut tercapai, sehingga guru dituntut untuk memahami karakteristik dari semua peserta didik yang dididiknya serta memilih strategi yang tepat digunakan untuk menyampaikan materi terhadap peserta didik.

Seperti yang terjadi di SMA Negeri I Sano Nggoang Kab. Manggarai Barat Provinsi Nusa Tenggara Timur, berdasarkan informasi yang diperoleh dari guru fisika kelas $\mathrm{X}$ yaitu Bapak Yosep Hamsu S.Pd menyatakan bahwa rata-rata hasil belajar fisika siswa khusunya untuk kedua kelas yaitu kelas XA dan kelas XB adalah rendah karena guru fisika tersebut hanya menggunakan satu motode saja yaitu metode ceramah.

Melihat permasalahan tersebut, maka solusinya untuk meningkatkan hasil belajar fisika siswa khususnya pada pokok bahasan suhu dan kalor. Salah satu cara yang dapat digunakan meningkatkan hasil belajar fisika siswa adalah strategi pembelajaran learning start with a question (LSQ) dengan strategi pembelajaran $a$ question student have (QSH). 
Strategi pembelajaran learning start with a question (LSQ) dengan strategi pembelajaran $a$ question student have (QSH) sudah banyak digunakan oleh peneliti-peneliti sebelumnya salah satunya Khaerun Najih pada mata pelajaran biologi dengan pokok bahasan ekosistem pada kelas VII SMP Negeri 30 Bulukumba. Rata-rata hasil belajar yang diperoleh dengan menggunakan strategi pembelajaran LSQ sebesar 65,25 sedangkan untuk strategi pembelajaran QSH sebesar 40,25.

Berdasarkan uraian diatas, peneliti mengadakan penelitian dengan judul "Perbandingan Hasil Belajar Fisika Peserta Didik antara Strategi Pembelajaran Learning start with a question (LSQ) dengan Strategi Pembelajaran a question Student have (QSH) pada Pokok Bahasan Suhu dan Kalor Kelas X SMA Negeri I Sano Nggoang Kab. Manggarai Barat Provinsi Nusa Tenggara Timur."

\section{Tinjauan Pustaka}

\section{Pengertian belajar}

Menurut Hilgard dan bower dalam ngalim purwanto, bahwa belajar berhubungan dengan tingkah laku seseorang terhadap suatu situasi tertentu yang disebabkan oleh pengalamannya yang berulang-ulang dalam dalam situasi itu, dimana perubahan tingkah laku itu tidak dapat dijelaskan atau dasar kecendrungan respon pembawaan, kematangan, atau keadaankeadaan sesaat seseorang (misalnya kelelahan, pengaruh obat, dan sebagainya).

\section{Hasil belajar}

Hasil belajar tersususun dari dua kata, yaitu "hasil" dan "belajar". Hasil adalah sesuatu yang didapat dari jerih payah. Sedangkan belajar adalah suatu upaya untuk memperoleh penguasaan kognitif, afektif, dan psikomotorik melalui proses interaksi antara individu dengan lingkungan.

Hasil belajar adalah perubahan perilaku secara keseluruhan bukan hanya salah satu aspek potensi kemanusiaan saja.

3. Pengertian Learning start with A question (LSQ)
Learning start with a question merupakan salah satu strategi belajar yang terkait dengan apresiasi. Lavanda dkk (25 Mei 2013) menyatakan bahwa Learning start with a question adalah strategi pembelajaran aktif dalam bertanya, dimana siswa dilibatkan langsung dalam proses pembelajaran. Pada metode ini siswa dituntut untuk aktif bertanya terutama pada awal pembelajaran, oleh karena itu siswa diminta mempelajarai terlebih dahulu materi yang akan disampaikan oleh guru. Senada dengan Silberman (2011: 157) yang menyatakan bahwa proses mempelajarai hal baru akan lebih efektif jika siswa dalam kondisi aktif bukan pasif.

Learning start with A question (LSQ) proses mempelajari sesuatu yang baru adalah lebih efektif jika peserta didik tersebut aktif. Mencari pula dari pada menerima saja. Salah satu cara untuk menciptkan belajar yang aktif adalah merangsang peserta didik untuk bertanya tentang materi pelajaran yang akan di pelajari, tanpa penjelasan dari pngajar terlebih dahulu. Strategi sederhana ini merangsang siswa untuk bertanya, kunci belajar.

4. Pengertian Strategi A question Student have (QSH)

A question Student have merupakan cara mudah untuk mempelajari keinginan dan harapan siswa. Teknik ini merupakan teknik yang tidak menakutkan yang dapat dipakai untuk mengetahui kebutuhan dan harapan peserta didik. Teknik ini menggunakan efesiensi dalam memperoleh partisipasai peserta didik secara tertulis.

\section{Metode Penelitian}

Penelitian ini merupakan penelitian eksperimen yang bertujuan untuk mengetahui apakah ada atau tidak pengaruh dari perlakuan yang diberi terhadap subyek yang diteliti. Lokasi penelitian ini berada di SMA Negeri 1 Sano Nggoang, Kab. Manggarai Barat, Nusa Tenggara Timur (NTT).

Desain penelitian yang digunakan dalam penelitian ini adalah "Kausal Komperatif". Populasi dalam penelitian ini adalah seluruh siswa kelas X SMA Negeri 1 Sano Nggoang yang berjumlah 88 siswa yang terbagi dalam 4 
kelompok belajar. Teknik pengambilan sampel dalam penelitian ini adalah purposive. Adapaun sampel dalam penelitian ini adalah siswa kelas XA (LSQ) sebagai kelas eksperimen 1 dengan jumlah siswa 22 orang dan kelas XB (QSH) sebgai kelas eksperimen 2 dengan jumlah siswa 22 orang. Adapun instrumen yang digunakan peneliti dalam penelitian ini adalah menggunakan tes dalam bentuk soal dengan jumlah soal pilihan ganda masing-masing 20 soal. Selain intrumen tes dalam bentuk soal yang digunakan oleh peneliti dalam penelitian ini, peneili juga menggunakan lembar observasi.

Teknik analisis data yang digunakan dalam penelitian ini adalah analisis deskriptif yang dimaksudkan untuk memperoleh nilai mean, standar deviasi, dan analisis inferensial terlebih dahulu dilakukan pengujian dasar yaitu uji normalitas dan uji homogenitas varians dan pengujian hipotesis digunakan untuk mengetahui dugaan sementara yang dirumuskan dalam hipotesis penelitian dengan menggunakan uji dua pihak.

\section{Hasil dan Pembahasan}

1. Deskripsi hasil belajar fisika peserta didik kelas XA yang diajar dengan menggunakan strategi pembelajaran LSQ.

Hasil analisis statistik deskriptif pada hasil belajar fisika siswa kelas XA diajar dengan menggunakan strategi pembelajaran LSQ dengan rata-rata hasil belajar yaitu 69,36.

Tabel 4.3: Kategori hasil belajar fisika siswa kelas XA yang diajar dengan menggunakan strategi pembelajaran LSQ.

\begin{tabular}{|c|c|c|c|}
\hline No & $\begin{array}{c}\text { Interval } \\
\text { kelas }\end{array}$ & Frekuensi & $\begin{array}{c}\text { Kategori hasil } \\
\text { belajar }\end{array}$ \\
\hline 1 & $0-34$ & 0 & Sangat rendah \\
\hline 2 & $35-54$ & 4 & Rendah \\
\hline 3 & $55-64$ & 3 & Sedang \\
\hline 4 & $65-84$ & 11 & Tinggi \\
\hline 5 & $85-100$ & 4 & Sangat tinggi \\
\hline
\end{tabular}

2. Deskripsi hasil belajar fisika peserta didik kelas XB yang diajar dengan menggunakan strategi pembelajaran QSH.
Hasil analisis statistik deskriptif pada hasil belajar fisika siswa kelas XA diajar dengan menggunakan strategi pembelajaran QSH dengan rata-rata hasil belajar yaitu 45,77 .

Tabel 4.6: Kategori hasil belajar fisika siswa kelas $\mathrm{XB}$ yang diajar dengan menggunakan strategi pembelajaran QSH.

\begin{tabular}{cccc} 
No & $\begin{array}{c}\text { Interval } \\
\text { kelas }\end{array}$ & Frekuensi & $\begin{array}{c}\text { Kategori hasil } \\
\text { belajar }\end{array}$ \\
\hline 1 & $0-34$ & 6 & Sangat rendah \\
\hline 2 & $35-54$ & 6 & Rendah \\
\hline 3 & $55-64$ & 5 & Sedang \\
\hline 4 & $65-84$ & 5 & Tinggi \\
\hline 5 & $85-100$ & 0 & Sangat tinggi \\
\hline \multicolumn{2}{c}{ Jumlah } & 22 &
\end{tabular}

3. Perbedaan hasil belajar fisika siswa yang diajar dengan menggunakan strategi pembelajaran (LSQ) dengan strategi pembelajaran (QSH) pada pokok bahasan suhu dan kalor.

Pada bagian ini dilakukan analisis statistik inferensial untuk mengetahui apakah ada perbedaan yang signifikan terhadap penggunaan strategi pembelajaran LSQ dan QSH terhadap hasil belajar fisika siswa kelas X SMA Negeri 1 Sano Nggoang.

\section{a. Uji Normalitas}

1) Uji Normalitas (Strategi Pembelajaran LSQ)

Hasil perhitungan uji normalitas untuk data hasil belajar fisika siswa kelas XA SMA Negeri 1 Sano Nggoang dengan menggunakan strategi pembelajaran LSQ diperoleh nilai Lhitung 0,103 dan nilai LTabel 0,190. Berdasarkan analisis tersebut, ternyata Lhitung $<$ LTabel sehingga dapat disimpulkan bahwa data pada penelitian ini untuk hasil belajar fisika siswa kelas XA SMA Negeri 1 Sano Nggoang dengan menggunakan strategi pembelajaran LSQ berdistribusi normal.

2) Uji Normalitas (Strategi Pembelajaran QSH)

Hasil perhitungan uji normalitas untuk data hasil belajar fisika siswa kelas XB SMA Negeri 1 Sano Nggoang dengan menggunakan strategi pembelajaran QSH diperoleh nilai Lhitung 0,1193 dan nilai LTabel 0,190. Berdasarkan analisis 
tersebut, ternyata Lhitung $<$ LTabel sehingga dapat disimpulkan bahwa data pada penelitian ini untuk hasil belajar fisika siswa kelas XB SMA Negeri 1 Sano Nggoang dengan menggunakan strategi pembelajaran QSH berdistribusi normal.

\section{b. Uji Homogenitas}

Hasil perhitungan uji homogenitas untuk data hasil belajar fisika siswa kelas XA dan siswa kelas XB SMA Negeri 1 Sano Nggoang diperoleh nilai Fhitung 1,365 dan nilai Ftabel 2,03. Berdasarkan analisis tersebut ternyata Fhitung $=$ $1,365<$ Ftabel $=2,03$ sehingga dapat disimpulkan bahwa data berasal dari populasi yang homogeny dalam taraf nyata 0,05 . Jadi kedua sampel dari data tersebut memiliki varians yang homogen.

\section{c. Pengujian Hipotesis}

Hasil pengujian hipotesis dengan menggunakan uji uji t-2 sampel independent diperoleh thitung sebesar 10,08 dan nilai ttabel sebesar 2,021. Hal ini terlihat bahwa nilai thitung $=10,08>$ ttabel $=$ 2,021 sehingga dapat disimpulkan bahwa H0 ditolak dan H1 diterima. Jadi kesimpulannya adalah terdapat perbedaan hasil belajar siswa antara kelompok siswa yang diajar dengan menggunakan strategi pembelajaran Learning start with A question (LSQ) dan siswa yang diajar dengan strategi A question Student have (QSH) pada pokok bahasan suhu dan kalor siswa kelas $\mathrm{X}$ SMA Negeri 1 Sano Nggoang.

Berdasarkan penelitian yang dilakukan di kelas X SMAN 1 Sano Nggoang dapat disimpulkan bahwa terdapat perbedaan hasil belajar fisika siswa antara kelas eksperimen 1 dengan kelas eksperimen 2 dimana rata-rata skor hasil belajar kelas eksperimen 1 lebih tinggi yaitu 69,36 sedangkan rata-rata skor hasil belajar kelas eksperimen 2 lebih rendah yaitu 45,77. Hal ini menunjukkan bahwa siswa yang diajar dengan menggunakan strategi pembelajaran LSQ memiliki hasil belajar yang lebih tinggi.

Pada dasarnya penggunaan strategi pembelajaran learning start with a question (LSQ) dan a question student have (QSH) dalam materi suhu dan kalor bertujuan untuk meningkatkan hasil belajar siswa dengan cara membuat pertanyaan yang berhubungan dengan materi yang belum dipahami. Hal ini selaras dengan Zaini (2007:16), yang menyatakan bahwa suatu strategi yang menuntut siswa bertanya dalam bentuk tulisan. Selain itu penelitian ini relevan dengan penelitian yang dilakukan oleh Yuli Henriyani, Ani Oktaria dan Kiki Anjawawi bahwa pembelajaran menggunakan strategi pembelajaran learning start with a question dapat meningkatkan hasil belajar siswa.

\section{Kesimpulan}

Berdasarkan hasil penelitian yang telah diuraikan maka dapat disimpulkan bahwa :

1. Hasil belajar siswa dikelas XA SMA Negeri 1 Sano Nggoang dengan penerapan strategi pembelajaran Learning start with A question (LSQ) masuk dalam kategori tinggi dari 22 siswa dengan skor rata-rata hasil belajar siswa sebesar 69,36.

2. Hasil belajar siswa di kelas XB SMA Negeri 1 Sano Nggoang dengan penerapan strategi pembelajaran A question Student have (QSH) masuk dalam kategori rendah dari 22 siswa dengan rata-rata hasil belajar sebesar 45,77.

3. Terdapat perbedaan hasil belajar siswa antara kelompok siswa yang diajar dengan menggunakan strategi pembelajaran Learning start with A question (LSQ) dan siswa yang diajar dengan strategi A question Student have (QSH) pada siswa kelas X SMA Negeri 1 Sano Nggoang. Hasil belajar siswa antara kelompok siswa yang diajar dengan mengguanakan strategi pembelajaran Learning start with A question (LSQ) lebih tinggi dibandingkan hasil belajar siswa yang diajar dengan menggunakan strategi pembelajaran A question Student have (QSH). Perbedaan tersebut dapat dilihat pada skor rata-rata kelas eksperimen 1 dan kelas eksperimen 2 .

\section{Daftar Pustaka}

Purwanto, Galim. 1998. Psikologi Pendidikan. Bandung: PT Remaja Rosdakarya.

Rahayu Puji Lestari. "Perbandingan Penggunaan Strategi Pembelajaran Learning start with A question (LSQ) dengan Question Student have (QSH) terhadap Hasil Belajar Biologi Kelas VIII MTs Negeri Model Makassar 
Tahun Ajaran 2015/2016”. Skripsi, Makassar: Fak. Tarbiyah dan Keguruan UIN Alauddin Makassar. 2016.

Sutikno. M. Sobri. 2013. Belajar dan Pembelajaran. Lombok: Holistica.

Zaini Hisyam. 2008. Pembelajaran Aktif. Yogyakarta: Pustaka Insan Madani.

Misbahuddin. 2013. Analisis Data Penelitian dengan Statistik. Jakarta : Bumi Aksara. 